\title{
THE STUDENTS' RESPONSES TOWARD THE IMPLEMENTATION OF CROSSWORD PUZZLE IN TEACHING VOCABULARY TO THE SEVENTH GRADE STUDENTS IN ONE OF JUNIOR HIGH SCHOOL IN CIMAHI
}

\author{
Yeni Meliyani $^{1}$, Evie Kareviati ${ }^{2}$ \\ 1,2 IKIP Siliwangi \\ ${ }^{1}$ yenimeliyani454@student.ikipsiliwangi.ac.id ${ }^{2}$ ekareviati@gmail.com
}

\begin{abstract}
This research was intended to find out the students' responses toward the implementation of crossword puzzle techniques in teaching vocabulary to the seventh-grade students at Junior High School. A descriptive qualitative method was used in this study. In collecting data the researcher used two instruments: classroom observation throughout the implementation of crossword puzzle in the classroom and from students' interviews. The researcher chose class VII B as respondents which consisted of 35 students. From the result, the researcher concluded that teaching-learning vocabulary by using crossword puzzle made the students' easy to memorize the vocabulary and made the students' more active in the class and the result also showed good responses from students, most of students felt interest and like to learn vocabulary in a descriptive text by using crossword puzzle.
\end{abstract}

Keywords: Crossword Puzzle, Students' Vocabulary Mastery

\section{INTRODUCTION}

Learning English is to make the learners be able to communicate both in oral and written forms. In learning English there is four importance aspect, namely listening, speaking, reading, and writing that should be mastered. However, mastering vocabulary is very important. If the students master a lot of vocabulary, it will be easier for students to convey what they mean, ideas, and feelings. It is deal with Thornbury's statement (2002:13) cited in Melasari, Ismawati, and Nanda (2019) that without grammar very little can be conveyed, without vocabulary nothing can be conveyed. Vocabulary is one of the aspects of language that cannot be separated from learning English because vocabulary is a main of language learning this statement supported by Richards and Renandaya (2002) as cited in Fahrurrozy (2015) cited in Hamer and Rohimajaya (2018) said that vocabulary is a core component of language proficiency and provides much of the basis how well learners speak, listen, read, and write. Before students study about four aspects in Language student should master vocabulary first in order that makes it easier for them to learn the four aspects of the language. This statement supported by Richard (2001:4) in Anwar and Efransyah (2018) cited in Sadiyah, Septiani, and Kareviati (2019) vocabulary is one of the most obvious components of language and one of the first things applied linguists turned their attention to.

In reality, most of the students still lack in mastering vocabulary. Because the teacher usually tends to use a traditional technique in teaching vocabulary, the teacher teaches vocabulary just to let students know about the word and then just tell students to memorize it. However, the 
teacher must teach vocabulary by providing students with the knowledge and understanding to apply it to real contexts to help students easily understand the vocabulary.

Based on the problems above, by creating a new learning atmosphere and attracting students' attention to more enthusiasm in learning there must be a change in the way the material is delivered to students. Prasetyo, Kurniawati, and Subari (2013) cited in Melasari, Ismawati, and Nanda (2019) state that "English teachers should apply various media to improve students' ability in mastering English skill". And based on the statement above Wilkin (1983: 14) cited in Ismawati, Sutarsyah, \& Nurweni, A. (2016) said that to increase students' interest and motivation to pay attention to the teaching and learning process in the classroom, the teacher should find out relevant techniques.

As Case (1994:5) in Melasari, Ismawati, and Nanda (2019) claims that puzzles are useful for language learners because enjoyment, satisfaction, reflection, and play can focus learners' attention on the language in a concentrated but not nonstressful way. As mentioned above the researcher wants to apply a technique in the form of a crossword puzzle to attract the attention of students.

According to Widyasari (2010) cited in Sadiyah, Septiani \& Kareviati (2019) there are some kinds of crossword puzzles that can be performed in the process of teaching and learning vocabulary in the classroom, there are :

a. An oral puzzle, it is a puzzle that is giving oral by teachers, and students are given only an empty crossword puzzle without a clue. Give instructions orally can train hearing students. Tell students to fill out what they could and then repeat the instructions until they understand.

b. A picture puzzle, it is a puzzle using picture as a clue. And only give the students the puzzle without the clue. For each clue, replaced with picture. It works very well with a unit embraced many new vocabularies.

c. An object puzzle, it is the crossword where inside the object is written a clue. Give a blank puzzle without a hint to the students. The goods placed around the room, each given a labeled with prompts number. Then the students are asked to go around at different stations allow them to pick up the objects as they complete the puzzle

However, from kinds of crossword puzzles above in this study, the researcher only focuses on using Object puzzles in the process of teaching and learning vocabulary in the classroom. Therefore, the researcher chose to implement a Crossword puzzle as a technique in teaching vocabulary to seventh-grade students aimed to find out the students' responses and the researcher expected can give the students motivation in learning English vocabulary.

\section{Vocabulary}

Langan's statement (1997) cited in Farizawati (2016), vocabulary is very important as a part of effective communication. Mastering a lot of vocabulary can make a speaker, listener, reader, and writer especially for students can be easier to learn the English Language, the acquisition of vocabulary is a key factor in successful language learning.

Montgomey (2007) as cited in Anwar and Efransyah (2018) states that there is a list of kinds vocabulary, where each type of vocabulary has a different purpose and vocabulary development in one facilities growth in another.

1. Speaking Vocabulary. It is the words that people use in their speech. 
2. Listening Vocabulary. It is the words that people hear and understand.

3. Writing Vocabulary. It is the words which are people use in writting either in formal or informal forms.

4. Reading Vocabulary. It is the words which are people know and understand when reading text.

Based on the statement above, hope the students more easily understand the lesson in the teaching-learning process using crossword puzzle, and students will learn a lot of new vocabulary at each meeting in the teaching and learning process in the classroom.

\section{Crossword Puzzle}

According to Njoroge, Ndung'u and Ganthigia (2013) cited in states Puspita and Sabiqoh (2017) that "the crossword puzzle is a game that makes the teaching-learning process attractive and funny, and also allows for students to practice and repeat the sentence pattern and vocabulary". As has been stated by Soeparno (1980:73) cited in Melasari, Ismawati, \& Nanda (2019) a crossword puzzle is a type of game that is done by filling in a blank form presented with letters those form words in the response of question given.

Based on Pinuria, Harmaini and Ernati (2014) as cited in Puspita and Sabiqoh (2017) procedures of using crossword puzzle, there are as follows:

Pre-teaching activity

1. The teacher greets the students.

2. The teacher checks students' attendance.

3. The teacher reminds the students about the previous subject taught in the last meeting.

4. The teacher introduces a new topic to the students.

Whilst-teaching activities

1. The teacher asks the students about the crossword puzzle.

2. The teacher gives an example of the crossword puzzle to the students.

3. The teacher gives assignments to the students.

4. After the teacher checks the answer of students, the teacher discussed with the students to make a sentence using the appropriate words as the crossword puzzle answer.

Post-teaching activities

1. The teacher asks the students about the crossword puzzle.

However, in implementing the Crossword Puzzle in teaching vocabulary to students, the researcher modified several steps.

In the first meeting the researcher explained about the crossword puzzle by giving examples and how to play it in the classroom. Almost all students already understood how to play and were very interested in trying it out. Then the researchers allowed some students to come forward and fill in the puzzle that was already available on the board, then after the students came forward the researcher mentioned the clue to fill the puzzle. Because the number of students is quite large namely 35 students, the researcher decided to use cooperative learning techniques and divide students into four groups which the group would use in each meeting. Before ending the study the researcher informed that the material for the next meeting was about a descriptive text.

At the second meeting, the material will be taught about the descriptive text. The researcher explained the definition of the descriptive text. The researcher asks students to sit with the 
group. Then after all students gathered with their groups researcher immediately gave a descriptive text that explained the animals and instructed them to be discussed with their friends. After all students have finished reading and discussing the text then the researcher gives assignments to each group. The assignment is in the form of a crossword puzzle that must be filled in and questions or clues are provided based on the text that has been read by students to help students fill in the puzzle. All groups are very compact, helping each other to find answers, they seem to enjoy and try to fill the puzzle faster. Then the researchers asked representatives from each group to come forward and discuss the answers they had worked on. After they answer all the puzzles unconsciously they get a new vocabulary.

In the third meeting, the researchers immediately gave the task to fill the crossword puzzle about adjectives. Then after that, as usual, the researcher asked one representative from each group to come forward to write the answer on the blackboard, and discuss the meaning of each vocabulary. Then after everything is finished and understand about the adjectives the researcher gives the task to describe the friend beside him by using the vocabulary that was discussed earlier.

In the last meeting, researchers have prepared a puzzle containing hidden vocabulary. The vocabulary in the puzzle is the vocabulary discussed in the previous meeting, the purpose is to review the vocabularies. The task is that all students must find as many vocabularies as possible in the puzzle, whoever finds the most vocabulary and completes it quickly then is the one who gets the best grades. Students look very happy and are competing to be able to find as much vocabulary as possible and one by one they come forward to mention the vocabulary they have found.

\section{METHOD}

This study used a descriptive qualitative design. As Bogdan and Biklen (1984) cited in Lelawati, Dhiya, and Mailani (2018) states that qualitative research has the natural setting as the direct source of data and the researcher is the key instrument. The data will be collected in the form of descriptive data describing a given state of affairs as fully and carefully as possible.This research is include in qualitative research because the researcher will be the main instrument (an observer) in collecting the data in a natural setting without doing any manipulation.

In this study the researcher was conducted in SMP in Cimahi with the participants of the study students of seventh grade. The total numbers of students are 35 with the specification of male 21 students and female 14 students. The data were obtained from classroom observation and interview.

\section{RESULTS AND DISCUSSION}

\section{Results}

In this result the data from interview four students of the implementation Crossword puzzle. The data from interview is as follows.

\begin{tabular}{lll}
\hline No & Question & Students' Responses \\
\hline $1 . \quad$ Do you like to learn English? & $\begin{array}{l}\text { All of them stated that } \\
\text { they like to learn English. }\end{array}$ \\
\hline
\end{tabular}


2. Do you like it when the teacher Three of them stated that teaches you about vocabulary? they like to learn vocabulary because it is easier when to speaking English . Meanwhile, one of them did not like to learn vocabulary because it is hard to memorize.

3. When you are told to memorize vocabulary, do you feel difficulties or not?
Some of the students stated that they did not feel difficult to memorize vocabulary because they are really like to learn English. Meanwhile two of the students stated that they feel difficult to memorize it because the pronunciation is difficult.

4. Do you think learning vocabulary with crossword puzzles is effective?

The students stated that learning vocabulary with a crossword puzzle is effective. They are felt fun and more active in the teaching-learning process.

5. What do you think when the teacher uses the crossword puzzle game when teaching vocabulary?

All students said they were happy when learning vocabulary using crossword puzzle. They do not feel bored and very happy.

6. Do you think learning using They are stated that the crossword puzzle helps you to crossword puzzle did mastery vocabulary? help them to mastery a lot of vocabulary.

7. Do you think studying in a group is Most of the students said effective? that studying in groups was effective. The reason, it can be faster to complete the assignment and can work together with other friends.

8. Do you prefer to learn vocabulary by All of respondents stated a crossword puzzle? that they prefer to learn vocabulary using crossword puzzle.

9. Does learning vocabulary by using a The students said that the crossword puzzle make you crossword puzzle motivated in learning English? 


\section{Discussion}

As a result of interview and observation could be concluded that all respondent said that crossword puzzle technique can make the students' motivated and enthusiasm in the teachinglearning process especially vocabulary. It is supported by the data from classroom observation. Observing teaching vocabulary using a crossword puzzle game was done three meeting and described as follows:

a. In the first meeting the teacher ran the steps based on Pinuria, Harmaini and Ernati as cited in Puspita and Sabiqoh (2017).

b. In the first and second meetings, the teacher still used the same steps, however in the second meeting the teacher modified the steps by her own.

c. In the last meeting, the teacher review all of the material that has been taught and given the students assignment.

In this part, the researcher would like to discuss about the result of the process of teaching vocabulary by using a crossword puzzle.

First, from the data gained through observation the researcher assumed that the teaching and learning vocabulary by using a crossword puzzle was made the students' easy to memorize the vocabulary and make them more active in the class.

Second, the result of the interview also showed that most of the students felt interested and really like to learned vocabulary used crossword puzzles.

From the data of observation that has taken from third meetings, the teacher did not find any difficulties during implementing crossword puzzles in the teaching and learning process. The teacher could run the steps well and the students got involved and enjoy the learning process actively. After analyzing the result from the interview and observation shows that teaching vocabulary using a crossword puzzle can increase students' vocabulary mastery. This statement supported by theory from Case (1994) cited in Sadiyah, Septiani, and Kareviati (2019) that puzzles are useful for language learners because of enjoyment, satisfaction, reflection, and play focus learners attention on the language in a concentrated but nonstressed way.

\section{CONCLUSION}

Referring to the information and discussion stated above, it can be concluded that the implementation of the crossword puzzle in teaching vocabulary process is running well and made the students feel motivated, enjoyable, and looked enthusiastic in following the teachinglearning process. It can be seen through students' responses when the teacher asked in the interview section. The students always asked the teacher when they found difficult words and the passive students become more active. This means that the implementation of a crossword puzzle in teaching vocabulary can help students' vocabulary mastery in seventh-grade students of a school in Cimahi.

\section{ACKNOWLEDGMENTS}

First of all, the researcher would like to thanks and praise to Allah SWT, who had let her finish this research, entitled "The Implementation of Crossword Puzzle in Teaching Vocabulary at Seventh Grade Student of School in Cimahi”. And thanks to IKIP Siliwangi especially the 
English Education Study Program, also the greatest appreciation to Mrs. Evi Kareviati, for her advices, supervision, and crucial contribution to the improvement of the result of this research.

\section{REFERENCES}

Anwar, Y., \& Efransyah. (2018). Teaching Vocabulary Using Crossword Puzzle Game at The Seventh Grade Students. Professional Journal Of English Education. 1:23.

Farizawati, F. (2016). Using Storytelling For Teaching Vocabulary. English Education Journal, 7(2), 246-259.

Hamer, W., \& Rohimajaya, N, A. (2018). Using Flash Card as Intructional Media to Enrich the Students' Vocabulary Mastery in Learning English. Journal of English Language Studies. 3:2.

Ismawati, L., Sutarsyah, C., \& Nurweni, A. (2016). Teaching Vocabulary Using Storytelling. University of Lampung, Lampung.

Lelawati, S., Dhiya, S., \& Mailani, P.N. (2018). The Teaching of English Vocabulary to Young Learners. Professional Journal of English Education. 1:2.

Melasari, Ismawati, K,. \& Nanda, D.S. (2019). The effect of using crossword puzzle towards students' vocabulary mastery in the eleventh grade students of SMA muhammadiyah 2 bandar lampung in academic year 2017-2018. Journal of English Education Studies. 2:1 67-73.

Sabiqoh, N. (2017). Teaching Vocabulary By Using Crossword Puzzle At The First Semester Of The Seventh Grade Students Of Mts Ma'arif Nahdlatul Ulama (Nu) 08 Mataram Baru In East Lampung In The Academic Year Of 2016/2017 (Doctoral dissertation, UIN Raden Intan Lampung).

Sadiyah, W. H., Septiani, W., \& Kareviati, E. (2019). Improving English Vocabulary Mastery By Using Crossword Puzzle. PROJECT (Professional Journal of English Education), 2(2), 110-114. 